\title{
CHARACTERIZATION AND PHYSICO-CHEMICAL ANALYSIS OF ESSENTIAL OIL OF Cymbopogon citratus LEAVES
}

\author{
*Olayemi, R.F. Jawonisi, I.O. and Samuel, J.A. \\ Department of Applied Science, School of Science and Technical Education, \\ College of Science and Technology, Kaduna Polytechnic. Kaduna. Nigeria \\ *Correspondence authorrianatfo@gmail.com
}

\begin{abstract}
The genus Cymbopogon is important from the point of view of their essential oils. Essential oils from these species are widely used in flavours, fragrances, cosmetics, soaps, detergents and perfumery owing to their typical lemon-like aroma. Essential oil of Cymbopogon citratus was extracted by hydrodistillation and characterized using Gas chromatography/mass spectrometry (GC-MS) and Fourier Transform Infrared(FTIR).The oil was also subjected to physico-chemical analysis, the physical and chemical properties evaluated were Boiling point $\left(74^{\circ} \mathrm{C}\right)$, Specific gravity (0.8960), Refractive index (1.4838) and $\mathrm{pH}(6.00)$ at $25^{\circ} \mathrm{C}$. Saponification value(109.76) and Acid value(0.55) $\mathrm{mg} \mathrm{KOH/g}$ oil. Iodine value(100g of $I_{2} / g$ oil) 105, Ester value(189.21), Residue on evaporation (10\%) at $100^{\circ} \mathrm{C}$.The chemical composition of the essential oil analyzed by GC-MS showed citral(31.1\%), 3 -Myrcene(14.2\%), citronellal (9.8\%),limonene oxide(7.7\%), geraniol (7.3\%) and linalool (6.2\%) as the major compounds. The FTIR spectra revealed the presence of n-alkane, conjugated alkene, primary amide, amine, aldehyde, primary and secondary alcohols. The results obtained from the physico-chemical parameters, and functional groups identified by FTIR as well as the compounds identified by GC-MS revealed that the oil has medicinal and nutritive values as well as industrial applications in the pharmaceutical, perfumery and cosmetic industries . Key words: Characterization, Citral, Cymbopogon citratus, Essential oil, FTIR, GC-MS.
\end{abstract}

\section{INTRODUCTION}

Cymbopogon citratus is a perennial grass plant belonging to the family Gramineae, known as lemongrass, comprising approximately 500 genus and 8000 herb species (Barbosa et al., 2008). The prefix 'lemon' owes to its typical lemon like odour, which is mainly due to the presence of citral, a cyclic monoterpene - a major constituent of essential oils of Cymbopogon species as well as citrus fruits, (Karkala and Bhushan, 2014). Lemon grass is a tufted perennial grass growing to a height of 1 meter with numerous stiff leafy stems arising from short rhizomatous roots (Carianne de Boer, 2005) .The leafblade is linear, tapered at both ends and can grow to a length of $100 \mathrm{~cm}$ and width of $2 \mathrm{~cm}$. Lemon grass is a perennial grass plant widely distributed worldwide and most especially in tropical and subtropical countries (Francisco et al., 2011). Several reports have linked its origin to Asia, Africa and the Americas. When squeezed, the leaves usually produce yellow or amber coloured, aromatic, essential oil (Adejuwon and Esther, 2007). It is also grown as an ornamental plant and the essential oil of the plant is used in aromatherapy.

Lemongrass is a folk remedy for coughs, elephantiasis, flu, gingivitis, headache, leprosy, malaria, ophthalmic, pneumonia and vascular disorders. Essential oils from the aerial parts of different species of Cymbopogon have folkloric medicinal use in fever, digestive disorders, diabetes, inflammation and nerve disorders (Joeng et al.,2009). Mixed with pepper, it is a home therapy for menstrual troubles and nausea (Belewu et al.,2011).Traditionally, tea made from lemongrass leaves is popular among countries of South America, Asia and West Africa having been widely utilized as antiseptic, antifever, antidyspeptic, carminative and anti-inflammatory effects. Others are febrifuge, analgesic, spasmolytic, antipyretic, diuretic, tranquilizer and stomachic agent (Negrelle and Gomes, 2007; Adejuwon and Esther, 2007; Tatiana and José 2011).

The study is aimed at determining the physicochemical properties as well as the functional groups present in the essential oil of lemon grass obtained in Kaduna in order to ascertain its purity and suitability for nutritive, pharmaceutical and various industrial applications reviewed in the literature, and also deduce the components already established by GC-MS in the literature. All these will then confirm the medicinal values claimed by the herbal medicine practitioners in folk medicine.

\section{MATERIALS AND METHODS}

Plant material and sample preparations

Lemongrass was obtained from Federal College of Forestry, Afaka, Kaduna. After harvesting, the leaves were separated from stalks and then air-dried at room temperature for five days. After drying, the leaves were cut into small pieces at the length of 4 to $8 \mathrm{~mm}$. Extraction of essential oil

Dried leaves $(500 \mathrm{~g})$ of Cymbopogon citratus were subjected to hydrodistillion for 3 hours in a Clevengertype apparatus. Distillates of essential oil was dried over anhydrous sodium sulphate, filtered and stored at $4^{\circ} \mathrm{C}$ until analyzed (Yehouenou et al., 2012).

Determination of Physico-chemical Properties of the oil

Boiling point, Refractive index, Specific gravity, $\mathrm{pH}$, Iodine value, Saponification value, Acid value, Residue on evaporation, Ester value were determined using standard analytical techniques British Pharmacopoeia, (B P,1980) and Association of Official Analytical Chemists (AOAC, 2005). 
Iodine value and saponification number were determined according to (AOAC, 2005). Official Methods 920.158 (Hanus method) and 920.160, respectively. Specific gravity was determined at $25^{\circ} \mathrm{C}$ using a $25 \mathrm{ml}$ capacity pycnometer. Refractive index was measured with an Abbe refractometer (Bellinghan, and Stanley Ltd, UK).

\section{Determination of Functional Groups}

The Infrared spectroscopy was carried out Shimadzu FTIR 8400s.

\section{Gas Chromatography}

GC analysis were performed on an orion micromat 412 double focusing gas chromatography system fitted with two capillary columns coated with CP-Sil 5 and CP-Sil 19 (fused silica, $25 \mathrm{~m} \times 0.25 \mathrm{~mm}, 0.15 \mu \mathrm{m}$ film thickness) and flame ionization detector (FID). The volume injected was $0.2 \mu \mathrm{L}$ and the split ratio was $1: 30$. Oven temperature was programmed from $50^{\circ} \mathrm{C}$ $230^{\circ} \mathrm{C}$ respectively. Qualitative data were obtained by electronic integration of FID area percents without the use of correction factors.

\section{Gas Chromatography/mass Spectrometry}

A Hewlett Packard (HP 5890A) GC interfaced with a VG Analytical 70-250S double focusing mass spectrometer was used. Helium was the carrier gas at $1.2 \mathrm{ml} / \mathrm{min}$. The MS operating conditions were: ionization voltage $70 \mathrm{ev}$, ion source temperature $230^{\circ} \mathrm{C}$. The GC was fitted with a $25 \mathrm{~m} \times 0.25 \mathrm{~mm}$, fused silica capillary column coated with CP-Sil 5 . The film thickness was $0.15 \mu \mathrm{m}$, the GC operating conditions were identical with those of GC analysis. The MS data were acquired and processed by online desktop computer equipped with disk memory. The percentage compositions of the oil were computed in each case from GC peak areas. The identification of the components was based on the retention indices (determined relative to the retention times of series of n-alkanes) and mass spectra with those of authentic samples and with data from Literature (Jennings and Shibamoto, 1980; Adams, 1995; Joulang and Konig, 1998).

\section{Kovats Retention Index System}

In the 1950s, the Kovats retention index system was introduced in gas chromatography (Kovats, 1958). The Kovats retention index KI, is defined and calculated by the following equation:

$$
\mathrm{KI}=100 \mathrm{~N}+100 \mathrm{n} \quad \frac{\log t^{1} \mathrm{R}_{\mathrm{A}}-\log t^{1}}{\left.\log t_{(\mathrm{N})}^{1}+\mathrm{n}\right)-\log t_{\mathrm{R}(\mathrm{N})}^{1}}
$$

Where $t^{1}{ }_{R(N)}$ and $t^{1}{ }_{R(N+n)}$ are the adjusted retention times of $\mathrm{n}$ - paraffin hydrocarbon of carbon number $\mathrm{N}$ and $(N+n)$ respectively, eluting before and after solute $A$ with the adjusted retention time $t^{1} R(A)$. Tables of retention indices can help identify constituents of the essential oil by comparing experimentally found retention indices with known values (Nic et al., 2006).

\section{RESULTS AND DISCUSSION}

The extracted oil was pale yellow in colour with a yield of $1.03 \%$. The physico-chemical parameters determined are listed in Table 1.The FTIR spectrum is shown in Fig 1, the functional groups associated with the absorption bands are listed in Table 2. Chemical composition of the oil determined using GC/MS are presented in Table 3.

Table 1:Physico-chemical Properties of Essential Oil of Cymbropogon citratus leaves

\begin{tabular}{ll}
\hline Parameter & Value \\
\hline Acid value $(\mathrm{mg} \mathrm{KOH} / \mathrm{g}$ oil $)$ & 0.55 \\
Ester value & 189.21 \\
Iodine value $\left(100 \mathrm{~g}\right.$ of $\mathrm{I}_{2} / \mathrm{g}$ oil) & 105 \\
$\mathrm{pH}$ at $25^{\circ} \mathrm{C}$ & 6.0 \\
Refractive index at $25^{\circ} \mathrm{C}$ & 1.4838 \\
Residue on evaporation at $100^{\circ} \mathrm{C}$ & $10 \%$ \\
Saponification value $(\mathrm{mg} \mathrm{KOH} / \mathrm{g}$ oil $)$ & 189.76 \\
Specific gravity at $25^{\circ} \mathrm{C}$ & 0.8960
\end{tabular}

The acid value is the weight of potassium hydroxide in mg required to neutralize the organic acids present in $1 \mathrm{~g}$ of the substance. The acid value may be overestimated if other acid components are present in the system, e.g. amino acids or acid phosphates. The acid value is often a good measure of hydrolytic rancidity which has an adverse effect on the quality of many lipids. In general, it gives an indication about edibility and pharmaceutical applications of the lipid. The result obtained in Table 1 indicated acid value 0.55 which is $<1$. Codex standard (2001) gave a value $\leq 0.60$.Therefore, the result obtained is within the range. $\mathrm{A} \mathrm{pH}$ of 6.0 recorded implies that the oil is not strongly acidic. These imply that the oil is suitable for pharmaceutical uses.

The saponification value is the number of $\mathrm{mg}$ of potassium hydroxide required to neutralize the free acids and to saponify the esters in $1 \mathrm{~g}$ of the substance. The saponification number is a measure of the average molecular weight of the triacylglycerols in a sample. The smaller the saponification number the larger the average molecular weight of the triacylglycerols present i.e. Saponification value is inversely proportional to the mean molecular weight of fatty acids (or chain length).Codex standard,(2001) gave a range of $186-195$, and the result of 189.76 obtained is within the range.

Refractive index is used mainly to measure the change in unsaturation as the oil is hydrogenated. The refractive index of oils depends on their molecular weight, fatty acids chain length, degree of unsaturation and degree of conjugation. It is a measure of how fast light travels through a substance and it is used to identify, confirm purity and measure concentration of the substance. The value obtained is within the range of the literature (1.469-1.479)(Codex standard,2001). 
The ester value is defined as the $\mathrm{mg}$ of $\mathrm{KOH}$ required to react with glycerin or glycerol after saponifying one gram of fat. It is calculated from the saponification value and the acid value: Ester value = saponification value - acid value.

The iodine value gives a measure of the average degree of unsaturation of a lipid: the higher the iodine value, the greater the number of $\mathrm{C}=\mathrm{C}$ double bonds. By definition the iodine value is expressed as the grams of iodine absorbed per $100 \mathrm{~g}$ of lipid. Iodine value is directly proportional to the degree of unsaturation (number of double bonds) and inversely proportional to the melting point of lipid. This value could be used to quantify the amount of double bonds present in the oil, which signifies the susceptibility of oil to oxidation. The value obtained was also within the range of established standard (104-120) (Codex standard, 2001).

Specific gravity is a ratio of densities which varies with temperature and pressure, therefore, reference and sample must be compared at the same temperature and pressure. Specific gravity is a parameter used to identify, measure concentration and confirm purity of substances. The value obtained 0.8960 is less than 1 , indicating that the oil is less dense than water. This is further established by the boiling point of $74^{\circ} \mathrm{C}$ indicating that the oil is volatile and therefore composed of light molecular weight components. Evaporation residue, in which the percentage of the oil that is not released at $100^{\circ} \mathrm{C}$ was determined. The result revealed $10 \%$ residue on evaporation implying that the oil is highly volatile as $90 \%$ of it was evaporated.

The FTIR spectra revealed the presence of alkene, primary amide, amine, aldehyde, alcohols, ketone, ester, carboxylic acid and ether. These functional groups identified are in agreement with compounds reported in the literature as well as the ones identified in the GC-MS analysis. For instance, citronellene, caryophyllene, a-pinene, $\beta$-myrcene and trans-abergamotene are alkenes. Geranial and citral are aldehydes, linalool, geraniol and terpeniol are alcohols, 6-Methyl-5-Hepten-2-one is a ketone, hexadecanoic acid and 9-octadecanoic acids are carboxylic acids.

Compounds such as hydrocarbon terpenes, alcohols, ketones, esters and mainly aldehydes have constantly been registered in the literature. Lemon grass contains active ingredients like myrcene, which is an alkene, citronellal, citral are aldehydes, citronellol and geraniol are alcohols. The biological activity of the essential oil obtained from $C$. citratus has been reported to be due to the presence of citronellal and citral (Joeng et al.,2009). Geranial, neral, geraniol, limonene, $\beta$-myrcene, citral have been found as major compounds in many other Cymbopogon citratus (Huynh et al., 2008).

Table 2: Funtional Groups Identified in Essential Oil of Cymbropogon citrates leaves

\begin{tabular}{lll}
\hline Absorption wave number $\left(\mathbf{c m}^{\mathbf{- 1}}\right)$ & Functional groups & Remark/inference \\
\hline $3486-3445$ & $\mathrm{~N}-\mathrm{H}$ & Primary amide, amine \\
$3026-2800$ & $\mathrm{C}-\mathrm{H}$ & Alkene, aromatic ring \\
$3000-2500$ & $\mathrm{O}-\mathrm{H}$ & Carboxylic acid \\
$1750-1650$ & $\mathrm{C}=\mathrm{O}$ & $\begin{array}{l}\text { Aldehyde, ketone, ester, } \\
\text { carboxylic acid }\end{array}$ \\
$1360-1180$ & & Amine \\
$1300-1000$ & $\mathrm{C}-\mathrm{N}$ & Alcohols, ether, ester, \\
& $\mathrm{C}-\mathrm{O}$ & Carboxylic acid \\
$1000-675$ & & Alkene \\
$870-675$ & $\mathrm{C}-\mathrm{H}$ & Aromatic ring
\end{tabular}

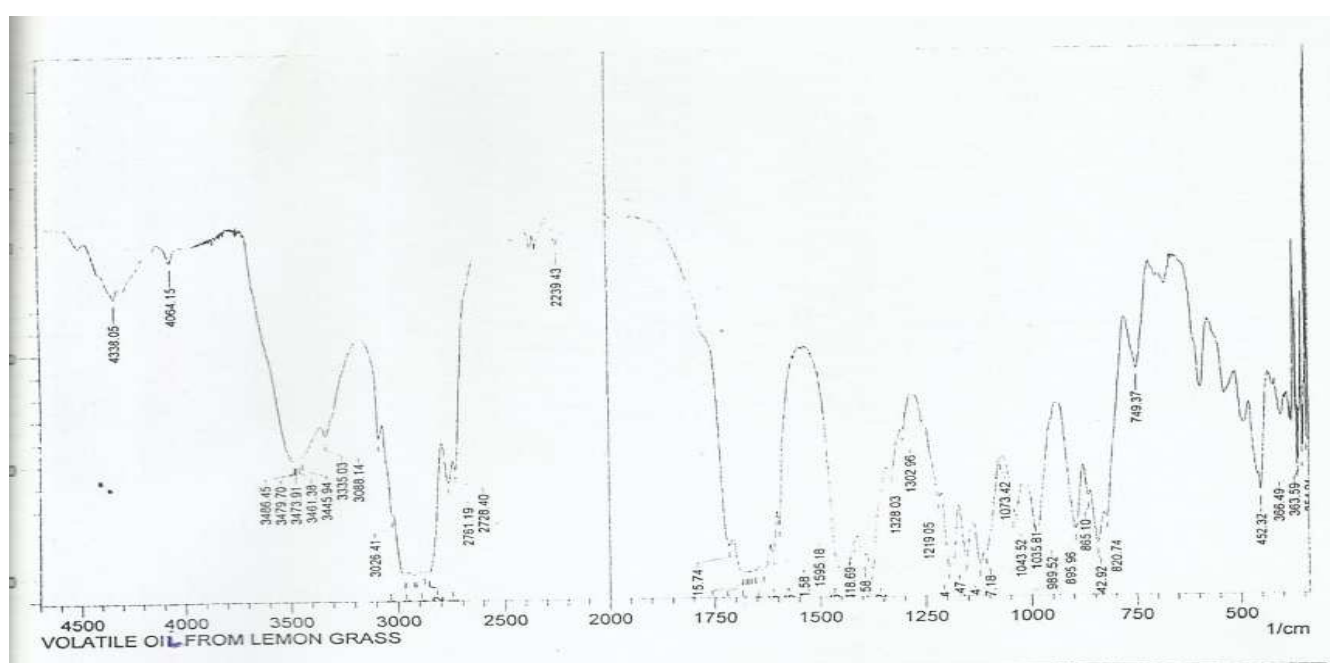

Fig 1: FTIR Spectra of Cymbopogon citratus leaf essential oil 
It has been documented in various literatures that essential oils of plant origin exhibit a wide spectrum of biological activities (Sacchetti et al., 2005). Biological activity of essential oils depends on their chemical composition (Chun et al., 2005), which can vary dramatically, even within the same species (Zapataa and Smagghea, 2010). Sources of compositional variability can include geographical origin of the plant, the plant part extracted, phenological state of the plant,

and time of year, as well as growth environmental conditions (Angioni et al., 2006; Isman et al., 2007). Biological activity of essential oils is also affected by interactions among their structural components. Even minor compounds can have a critical function due to additive action between chemical classes and synergism or antagonism (Sampson et al., 2005; Angioni et al., 2006; Bakkali et al., 2008).

The composition of Cymbopogon citratus essential oil is much more homogeneous, always with geranial and neral as the main constituents whatever the origin of the plant. The samples characterized in Burkina Faso (Menut et al., 2000), Brazil and Portugal (Franz et al.,2011), and Benin (Bossou et al.,2013) confirm this observation

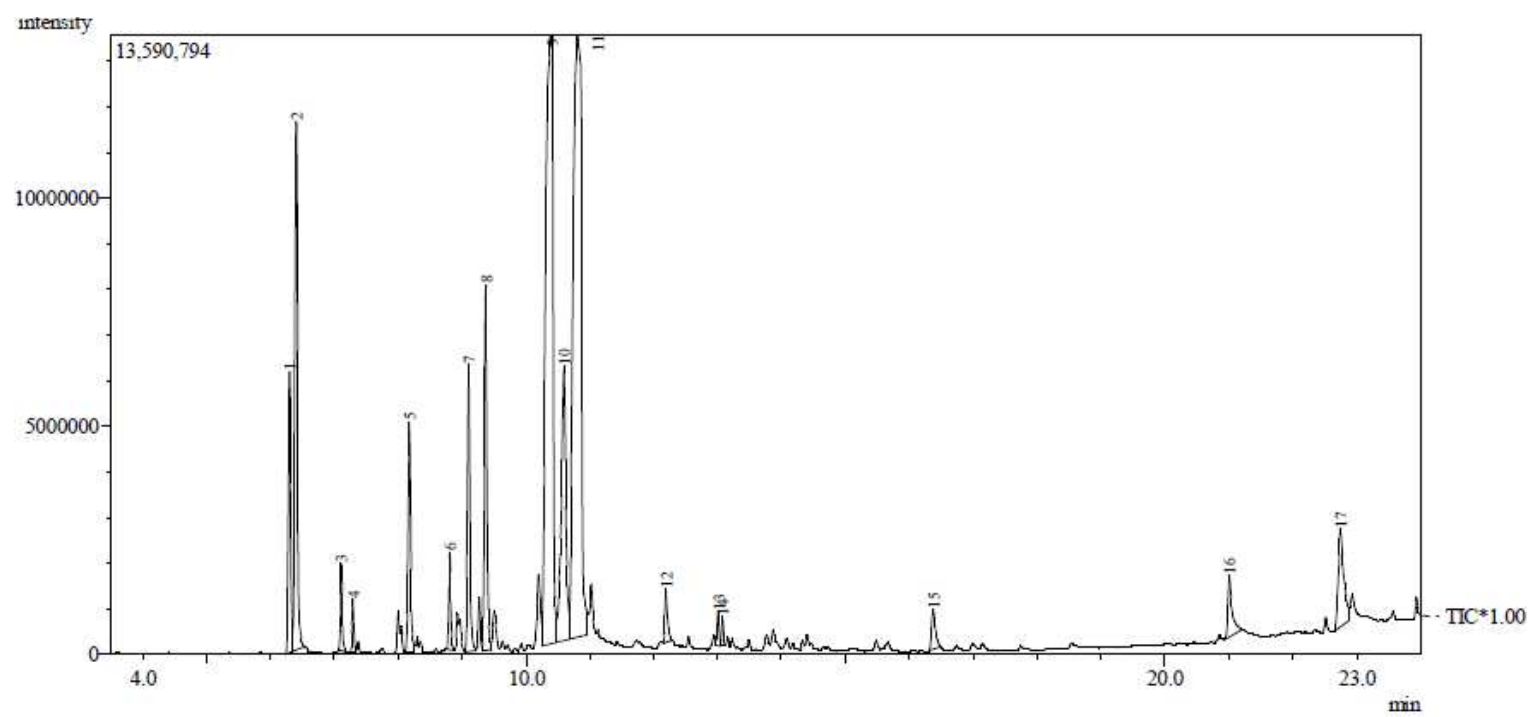

Fig 2 : Chromatogram of Cymbopogon citratus leaf essential oil

The chemical composition of the leaf essential oil of Cymbopogon citratus as listed in Table 3 revealed that geranial(18.8\%), neral(16.3\%), $\quad \beta$ myrcene(14.2\%), citronellal(9.8\%), limonene oxide(7.7\%),geraniol(7.3\%) and linalool(7.3\%) were the major compounds. A total of 16 compounds were identified representing $99 \%$ of the total oil. The oil was dominated by monoterpenes accounting for $88.9 \%$ of the total oil out of which monoterpene hydrocarbon was $20.3 \%$ whereas oxygenated monoterpene was $68.6 \%$.Sesquiterpene hydrocarbon accounted for an insignificant amount of $1.7 \%$, oxygenated sesquiterpene was absent whereas other non terpene components was $8.4 \%$. This result is in agreement with previous report by Koba et al.(2009) where lemon grass leaf essential oil consisted of two monoterpene hydrocarbon (10.6\%) and nine oxygenated monoterpenes (86.4\%). Sessou et al.(2012) also reported $9.9 \%$ for hydrogenated monoterpenes, oxygenated monoterpens $85.3 \%$, hydrogenated sesquiterpens $2.2 \%$ and oxygenated sesquiterpens $0.1 \%$ representing a total of $97.5 \%$ of the oil. This is an indication that essential oils of Cymbopogon species mainly consist of the monoterpene fractions.

The chemical composition of essential oil of cymbopogon citratus varies according to geographical origin, as a function of genetic diversity, habitat and agronomic treatment of the culture(Ganjewela et al.,2008; Khanuja et al.,2005). The compounds such as hydrocarbon terpenes, alcohols, ketones, esters and mainly aldehydes have constantly been registered. Lemon grass contains active ingredients like myrcene, an antibacterial and pain reliever, citronellal, citronellol and geraniol.

Citral - an isomeric mixture of geranial and neral are major components in the essential oils of several species of Cymbopogon (Shah et al., 2011; Huynh et al., 2008). Both citral and geraniol have immense commercial significance due to their characteristic lemon and rose-like smell in the flavour, fragrance, cosmetics, perfumery and pharmaceutical industries(Ganjewela et al.,2008; Dubey et al.,2003). Citral is used in the manufacture of perfumes, colored soaps, synthesis of vitamin $A$ and $\beta$-ionones and other specialty chemicals (Deepak et al.,2012; Mirghani et al., 2012). The biological activity of the essential oil obtained from $C$. citratus is due to the presence of citronellal and citral (Joeng et al.,2009), which plays important detoxification and anti-cancer roles in the body by inducing glutathione-S-transferase (GST) activity (Hedges and Lister,2006; Puatanachokchai et al., 2002). 
Citral possesses many significant bioactivities of great medicinal and pharmaceutical significance. It has antimicrobial activity against many microorganism strains such as Aspergillus flavus, Penicillium expansum, $A$. ochraceus, $P$. verrucosum, Listeria monocytogenes, S. aureus, E. coli, S. typhimurium (Burt, 2004; Nguefack et al., 2004, 2009, 2012). A number of reports published have substantiated citral for most of the bioactivities of lemongrass essential oils. Some of the activities of citral published recently are antimicrobial, antiparasitic, antispasmodic, analgesic, anti-inflammatory, antipyretic, diuretic and sedative (Ganjewala, 2009).

Furthermore, many studies have reported the antimicrobial activity of lemongrass oil originating from different parts of the globe against a diverse range of microorganisms comprising Gram positive and Gram negative bacteria, yeast and fungi namely Bacillus cereus, Bacillus subtilis, Escherichia coli, Klebsiella pneumoniae (Naik et al., 2010), Salmonella choleraesuis, Pseudomonas aeruginosa, Staphylococcus aureus (Falcão et al., 2012) and Aspergillus flavus, Aspergillus fumigatus, Aspergillus niger, Alternaria alternata, Penicillium citrinum, Curvularia lunata and Trichoderma harzianum (Mahanta et al., 2007). Also, (Shaaban, 2005) reported that the essential oil of Cymbopogon citratus can be used as a potential source of novel antimicrobial agent and can also be further exploited as an alternative food preservatives.

As can be seen in Table 3, a total of 16 compounds were identified in Cymbopogon citratus leaves representing $99.0 \%$ of the total oil. The oil was rich in monoterpenoids $(86.5 \%)$ dominated by oxygenated monoterpenes $\quad(58.8 \%) \quad$ with hydrogenated monoterpenes representing $27.7 \%$ of the oil content. Hydrogenated sesquiterpenes accounted for only $1.7 \%$ and oxygenated sesquiterpenes were not detected at all. Furthermore three non-terpene compounds (one ketone and two carboxylic acids) representing $10.8 \%$ of the total oil were also identified.

Among the constituents occurring in higher proportions, geranial (18.8\%), neral (16.3\%), $\beta$ - myrcene $(14.2 \%)$, citronellene $(9.8 \%)$, limonene oxide $(7.7 \%)$, geraniol $(7.3 \%)$ and linalool $(6.2 \%)$ were prominent, a-pinene $(2.3 \%)$, cis- $\beta$-ocimene $(1.4 \%)$, geranyl acetate $(1.4 \%)$ and terpineol were detected in appreciable quantities .The minor constituents were trans-a-bergamotene $(0.8 \%)$ and caryophyllene $(0.9 \%)$. The abundance of citral (geranial+neral) accounting for $35.1 \%$ of the total oil signifies that the oil is of citral chemotype. This sample appeared similar to previous reports on oil chemotypes from other parts of the world.

Based on literature data, geranial, neral, geraniol, limonene and $\beta$-myrcene have been found as major compounds in many other Cymbopogon citratus species with citral as the main chemical component of lemongrass oil (Huynh et al., 2008). In the data reported by Mirghani et al. (2012) for Malaysia specimen; they found a prominent composition in geranial $(29.64 \%)$, neral $(21.73 \%)$, geraniol $(7.75 \%)$, limonene $(5.92 \%)$ and $\beta$-myrcene $(2.28 \%)$. This composition is also similar to the data provided by Sessou et al.,2012 where geranial(44.5\%), neral(31.2\%), myrcene( $9.6 \%)$ and geraniol(7.9\%) were the main components of lemon grass essential oil from Benin. Also, Koba et al. (2009) reported geranial (45.2\%), neral (32.4\%) and myrcene $(10.2 \%)$ as the main components of essential oil of lemongrass specie from Togo. Matasyoh et al. (2011) found in lemongrass essential oil of Kenya, geranial $(39.53 \%)$, neral $(33.31 \%)$, and myrcene $(11.41 \%)$ as major compounds. Geranial (40.82-44.44\%), neral (33.56-33.54\%), and myrcene (13.60-14.78\%) were the major compounds isolated from essential oil of lemongrass cultivated in Brazil as reported by Rocha et al. (2011).

Loumouamou et al. (2010) analyzed essential oil of lemongrass of Congo- Brazzaville and found geranial $(48.88 \%)$ and neral $(36.24 \%)$ in prominent concentration. Lemongrass essential oil from Malaysia studied by Tajidin et al. (2012) contained geranial (37.58\%-45.95\%) and neral (29.4\%- $31.13 \%)$ as main components. Similarly, Bharti et al.(2013) reported geranial $(44.5 \%)$, neral $(31.2 \%)$, myrcene $(9.6 \%)$ and geraniol (7.9\%) as main compounds.

TABLE 3: CHEMICAL COMPOSITION OF ESSENTIAL OIL OF CYMBOPOGON CITRATUS LEAVES.

\begin{tabular}{|c|c|c|c|c|}
\hline $\mathrm{S} / \mathrm{N}$ & COMPOUND & KI & PERCENTAGE COMPOSITION & MASS SPECTRA DATA \\
\hline 1 & Citronellene & 926 & 9.8 & $95 \quad 8167 \quad 41$ \\
\hline 2 & 6-Methyl-5-Hepten-2-one & 938 & 6.5 & $126 \quad 108 \quad 69 \quad 55$ \\
\hline 3 & a-Pinene & 948 & 2.3 & 1211059377 \\
\hline 4 & $\beta$-Myrcene & 958 & 14.2 & $\begin{array}{llll}121 & 93 & 79 & 69\end{array}$ \\
\hline 5 & Cis- $\beta$-Ocimene & 976 & 1.4 & 1211059379 \\
\hline 6 & Trans-Limonene oxide & 1031 & 7.7 & $\begin{array}{llll}108 & 94 & 67 & 43\end{array}$ \\
\hline 7 & Linalool & 1082 & 6.2 & $\begin{array}{llll}136 & 121 & 93 & 71\end{array}$ \\
\hline 8 & Terpineol & 1137 & 1.1 & $136121 \mathbf{8 1} 43$ \\
\hline 9 & E-Citral(Geranial) & 1174 & 18.8 & $137 \quad 1096941$ \\
\hline 10 & Z-Citral(Neral) & 1174 & 16.3 & 1341098469 \\
\hline 11 & Geraniol & 1228 & 7.3 & $12393 \quad 6941$ \\
\hline 12 & Geranyl acetate & 1352 & 1.4 & $\begin{array}{llll}136 & 121 & 93 & 69\end{array}$ \\
\hline 13 & Trans-a-Bergamotene & 1430 & 0.8 & 2041199369 \\
\hline 14 & Caryophyllene & 1494 & 0.9 & 2041619369 \\
\hline 15 & Hexadecanoic acid & 1968 & 1.6 & $256129 \quad 73 \quad 60$ \\
\hline \multirow[t]{3}{*}{16} & 9-Octadecanoic acid & 2175 & 1.7 & $264 \quad 69 \quad 55 \quad 41$ \\
\hline & Total (\%) & & 99.0 & \\
\hline & $\begin{array}{l}\text { Total number of } \\
\text { compounds }\end{array}$ & & 16 & \\
\hline
\end{tabular}

KI (Kovats Index ) was calculated using a series of n-alkanes 
Bajopas Volume 11 Number 1 June, 2018

The same data was reported by Bassole et al. (2011) who found geranial (48.1\%), neral (34.6\%) and myrcene $(11.0 \%)$ as major constituents of Cymbopogon citratus essential oil from Burkina-Faso. Comparison of the chemical profile of the essential oil of Lemongrass (Cymbopogon citratus) from Nigeria with the reports of other scientist elsewhere, it can be established that there are significant quantitative differences between the chemical profiles of the major components of the oil. These variations may due to the diverse climatic and geographic differences and at the same time to different harvesting times and extraction procedures (Ashgari et al., 2010; Ranitha et al., 2014).

\section{CONCLUSION}

It is worthy of note that important pharmaceutical usage of lemon grass still remains under exploited especially in West Africa where these aromatic herbs are widely distributed. The study of the essential oil composition of various Cymbopogon species presented here led to the conclusion that the monoterpene compositions of the essential oils varied significantly among the species. Invariably, essential oil content and compositions are greatly influenced by climate, season and diurnal effects. All the physicochemical properties determined in this study are important properties to determine the chemical state and quality of the extracted oil. The established constituents of the oil also suggested that the oil has medicinal and nutritive values as well as industrial application in the synthesis of ionones and vitamin A. Monoterpene constituents of the essential oil have been reported of useful biological activities.

\section{REFERENCES}

Adams, R. P. (1995). Identification of Essential Oil Component by Gas Chromatography/Mass Spectroscopy. Allured Publishing Corp , Carol Stream, USA, p 469.

Adejuwon, A. A., and Esther, O. A. (2007). Hypoglycemic and hypolipidemic effects of fresh leaf aqueous extract of Cymbopogon citratus Stapf in rats. Journal of Ethnopharmacology,112:440-444.

Angioni, A., Barra, A., Coroneo, V., Dessi, S., and Cabras, P.(2006). Chemical composition, seasonal variability, and antifungal activity of Lavandula stoechas L. ssp. Stoechas essential oils from stem/leaves and flowers. J. Agric. Food Chem, 54: 4364-4370.

AOAC.(2005). Official methods of analysis (16th Ed.). Washington, DC: Association of Official Analytical Chemists .

Ashgari, J., Touli, C.K., and Mazaheritehrani, M. (2010). "Microwave-assisted hydrodistillation of essential oils from Echinophora platyloba DC," Journal of Medicinal Plants Research,6(28):4475-4480.

Bakkali, F., Averbeck, S., Averbeck, D., and Idaomar, M.(2008). Biological effects of essential oilsa review. Food Chem. Toxicol, 46: 446-475.

Barbosa, L.C.A., Pereira, U.A., Martinazzo, A.P., Maltha, C.R.A., Teixeira, R.R., and Melo,

\section{RECOMMENDATION}

One of the major problems related to the use of synthetic drugs is the development of resistance by microorganisms and the adverse effects associated with their use. For these reasons, treatment using plant-based medicine appears to be an alternative approach. Essential oils classified as Generally Recognized As Safe (GRAS) and considered at low risk for developing resistance to pathogenic microorganisms could be a credible alternative. However, aromatic plants and their extracts should be standardized and properly controlled in their extraction and composition, in order for the study of these plants to yield meaningful data.

For the practical use of this oil, further research is needed on safety issues for human health and acceptability by consumers. Identifying the main components of the essential oil, testing their safety, and phytochemical study to uncover their medicinal value in disease treatment will provide an important means for the development of novel drugs.

\section{Author's contributions:}

\section{Olayemi, R.F.}

Supervision of the research.

Interpretation of IR spectrum.

Characterization of GC/MS results.

Writing and proof reading of manuscript.

\section{Jawonisi, I.O.}

Determination of physic-chemical properties of the oil. Writing and proof reading of manuscript.

Supervision of the research.

\section{Samuel, J A.}

Sample collection and preparation.

Extraction of essential oil.

Conflict of interest: Authors declare no conflict of interest.

E.C.(2008). Evaluation of the Chemical Composition of Brazilian Commercial Cymbopogon citratus (D.C.) Staff Samples. Molecules,13:1864-1874.

Bassolé, I.H., Lamien-Meda, A., Bayala, B.B. et al.(2011).Chemical composition and antimicrobial activity of Cymbopogon citratus and Cymbopogon giganteus essential oils alone and in combination. Phytomedicine, 18: $1070-1074$.

Belewu, M.A., Okukpe, K.M., Oladipo, F.O. et al.(2011). Lemon grass(Cymbropogon citratus) : A plant for future medicinal edible oil. Medicinal Plants,3(2):169-171.

Bharti, S.K., Kumar, A., Prakash, O., Krishnan, S., and Gupta, A.K. (2013) Essential Oil of Cymbopogon Citratus Against Diabetes: Validation by In vivo Experiments and Computational Studies. J Bioanal Biomed, 5: 194-203.

Bossou, A.D., Mangelinckx, S., Yedomonhan, H. et al. (2013). Chemical composition and insecticidal activity of plant essential oils from Benin against Anopheles gambiae (Giles). Parasites \& Vectors, 6: 337.

British Pharmacopoeia,(1980) 1:20, University Press, Cambridge, U.K. 
Burt, S. (2004). Essential oils: their antibacterial properties and potential applications in fooda review. Int. J. Food Microbiol. 94: 223253.

Carianne de Boer.(2005). Organic lemongrass, a guide for small holders. EPOPA (Export Promotion of Organic Products from Africa)1-27.

Chun, S.S., Vattem, D.A., Lin, Y.T., and Shetty, K.(2005). Phenolic antioxidants from clonal oregano (Origanum vulgare) with antimicrobial activity against Helicobacter pylori. Process Biochem.40: 809-816.

Codex Standard( 2001).Codex Alimentarius. Named Vegetable Oils 8: 210.

Deepak, G., Ashish K. G., and Ritam, M.(2012). An Update on Bioactive Potential of a Monoterpene Aldehyde Citral. Journal of Biologically Active Products from Nature, 2 (4):186 - 199.

Dubey ,V.S., Bhalla, R., and Luthra, R.(2003). An overview of the non-mevalonate pathway for terpenoid biosynthesis in plants. J Biosci, 28:637-46.

Falcão, M.A., Fianco, A.L.B.,Lucas, A.M.,Pereira, M.A.A., Torres, F.C.,Vargas, R.M.F.,Cassel,E. (2012). Determination of antibacterial activity of vacuum distillation fractions of lemongrass essential oil. Phytochemistry, 11:5-13.

Francisco, V., Figueirinha, A., Neves, B. M., GarcíaRodríguez, C., Lopes, M. C., Cruz, M. T. and Batista, M. T. (2011). Cymbopogon citratus as source of new and safe anti-inflammatory drugs: bio-guided assay using lipopolysaccharide-stimulated macrophages. Journal of Ethnopharmacology ,133: 818827.

Franz ,A.R., Knaak, N., and Fiuza, L.M.(2011). Toxic effects of essential plant oils in adult Sitophilus oryzae (Linnaeus) (Coleoptera, Curculionidae). Revista Brasileira de Entomologia, 55: 116-120.

Ganjewala, D. (2009). Cymbopogon Essential oils: Compositions and Bioactivities. The Int. J.Eessent. Oil Therapt, 3 (2-3):1-10.

Ganjewala, D., Kumari, A., and Khan,K.H.(2008). Ontogenic and developmental changes in essential oil content and compositions in Cymbopogon flexuosus cultivars. In: Prasad BN, Lazer Mathew, editor. Recent Advance in Biotechnology. New Delhi, India: Excel India Publishers, p. 82-92.

Hedges, L.J., and Lister, C.E. (2006) Nutritional attributes of Brassica vegetables. Crop \& Food Research Confidential report no. 1618. New Zeal Inst Crop \& Food Res Ltd 46.

Huynh, K.P.H., Maridable, J., Gaspillo, P., Hasika, M., Malaluan, R., and Kawasaki, J. (2008). Essential Oil from Lemongrass Extracted by Supercritical Carbon Dioxide and Steam Distillation. Philipp. Agric. Sci, 91: 36 -41.

Isman, M., Machial, C., Miresmailli, S., and Bainard, L.(2007). Essential oil-based pesticides: new insights from old chemistry. In: Ohkawa, $\mathrm{H}_{\text {., }}$ Miyagawa, H., Lee, P. (Eds.), Pesticide Chemistry. Wiley-VCH, Weinheim, Germany, pp. 201-209.

Jennings, W., and Shibamoto, T.(1980). Qualitative analysis of flavor and fragrance volatiles by glass capillary column gas chromatography. Academic Press, New York.p248-250.

Jeong, M.R., Park, P.B., Kim, D.H. et al. (2009) Essential oil prepared from Cymbopogon citratus exerted an antimicrobial activity against plant pathogenic and medical microorganisms. Mycobiology, 37: 48-52.

Joulang, D., and Konig, W.A.(1998). The atlas of spectra data of sesquiterpene hydrocarbons.F.B. Verlay Hamburg, Germany.p115-123.

Karkala, M., and Bhushan, B.(2014). Review on pharmacological activity of Cymbopogon Citrates.International Journal of Herbal Medicine, 1(6): 5-7

Khanuja, S.P.S., Shasany, A.K., Pawar, A. et al.(2005). Essential oil constituents and RAPD markers to establish species relationship in Cymbopogon Spreng. (Poaceae). Biochem Syst Ecol,33:171-86.

Koba, K., Sanda, K., Guyon, C., Raynaud, C., Chaumont. J.C., and Nicod, L. (2009). In vitro cytotoxic activity of Cymbopogon citratus L. and Cymbopogon nardus L. essential oils from Togo. Bangladesh $J$. Pharmacol. 4: 29-34.

Kovats, E.(1958). Gas-chromatographische Charakterisierung organischer Verbindungen. Teil 1: Retentionsindices aliphatischer Halogenide, Alkohole, Aldehyde und Ketone. Helv. Chim. Acta, 51: 1915.

Loumouamou, A.N., Biassala, E., Silou, T., NtondeleNsansi, P., Diamouangana, M.J., Nzikou, J., Chalchat, J.C., and Figuérédo, G. (2010). Characterization of a Giant Lemon Grass Acclimatised in the Congo- Brazzaville. Adv. J. Food Sci. Technol, 2: 312-317.

Mahanta, J.J., Chutia, M., Bordoloi, M., Pathak, M.G., Adhikary, R.K., and Sarma, T.C.(2007). Cymbopogon citratus L. essential oil as a potential antifungal agent against key weed moulds of Pleurotus spp. spawns. Flavour Fragrance Journal, 22: 525-530.

Matasyoh, J.C., Wagara, I.N., Nakavuma, J.L., and Kiburai, A.M. (2011). Chemical composition of Cymbopogon citratus essential oil and its effect on mycotoxigenic Aspergillus species. Afr. J.Food Sci, 5: 138-142.

Menut, C., Bessiere, J.M., Samate, D., Djibo, A.K., Buchbauer, G., and Schopper, B.(2000). Aromatic plants of tropical West Africa XI: chemical composition, antioxidant and antiradical properties of the essential oils of three Cymbopogon species from Burkina Faso. Journal of Essential Oil Research, 12:207-212. 
Mirghani, M.E.S., Liyana, Y., and Parveen, J. (2012). Bioactivity analysis of lemongrass (Cymbopogan citratus) essential oil. Int. Food Res. J, 19: 569-575.

Naik, M.I., Fomda, B.A., Jaykumar, E., and Bhat, J.A.(2010). Antibacterial activity of lemongrass (Cymbopogon citratus) oil against some selected pathogenic bacteria's. Asian Pacific Journal of Tropical Medicine, 3(8): 535-538.

Negrelle, R. R. B., and Gomes, E. C. (2007). Cymbopogon citratus (DC.) Stapf: chemical composition and biological activities. Revista Brasileira de Plantas Medicinais ,9: 80-92.

Nguefack, J., Leth, V., Amvam Zollo, P.H., and Mathur, S.B. (2004). Evaluation of five essential oils from aromatic plants of Cameroon for controlling food spoilage and mycotoxin producing fungi. Int. $J$. Food Microbiol, 94: 329- 334.

Nguefack, J., Nguikwie, S.K., Fotio, D., Dongmo, B., Leth, V., and Nkengfack, A.E. (2007). Fungicidal potential of essential oils and fractions from Cymbopogon citratus, Ocimum gratissimum and Thymus vulgaris to control Alternaria padwickii and Bipolaris oryzae, two seed-borne fungi of rice (Oryza sativa L.). J.Essent. Oil Res, 19: 581-587.

Nguefack, J., Tamgue, O., Lekagne, J.B. et al.(2012). Synergistic action between fractions of essential oils from Cymbopogon citratus, Ocimum gratissimum and Thymus vulgaris against Penicillium expansum. Food Control, 23: 377-383.

Nic, M., Jirat, J., and Kosata, B., eds. (2006). "retention index, $\mathbf{I}$ in column chromatography". IUPAC

Compendium of Chemical Terminology (Online ed.). doi:10.1351/goldbook.R05360. ISBN 0-9678550-9-8.

http://goldbook.iupac.org/R05360.html Phytologist. 153 : 257-273.

Puatanachokchai, R., Kishida, H., Denda, A. et al. (2002). Inhibitory effects of lemon grass (Cymbopogon citratus, Stapf) extract on the early phase of hepatocarcinogenesis after initiation with

diethylnitrosamine in male Fischer 344 rats. Cancer Lett, 183: 9-15.

Ranitha, M., Abdurahman, H. N., Ziad, A. S., Azhari H. N., and Thana, R. S.(2014). A Comparative Study of Lemongrass (Cymbopogon Citratus) Essential Oil Extracted by Microwave-Assisted Hydrodistillation (MAHD) and Conventional Hydrodistillation (HD) Method. International Journal of Chemical Engineering and Applications, 5(2):104-108.
Rocha, R.P., de Castro Melo, E., Demuner, J.A., Radünz, L.L., José Bon Corbín, B.J. (2011). Influence of drying air velocity on the chemical composition of essential oil from lemongrass. Afr. J. Food Sci. Technol, 2: 132-139.

Sacchetti G, Maietti S, Muzzoli M. et al. (2005) Comparative evaluation of 11 essential oils of different origin as functional antioxidants, antiradicals and antimicrobials in foods. Food Chemistry, 91: 621- 632.

Sampson, B., Tabanca, N., Kirimer, N. et al. (2005). Insecticidal activity of 23 essential oils and their major compounds against adult Lipaphis pseudobrassicae (Davis) (Aphididae: Homoptera). Pest Manag. Sci, 61:1122-1128.

Shaaban, H.A.(2005). Evaluation of antimicrobial activities of lemon grass (Cymbopogon citratus) Essential oil.In The 2nd International Conference of the Food Industries \&Nutrition Division, NRC, Dokki, Giza, Egypt 27-29 Nov., pp: 321-332.

Shah, G., Shri, R., Panchal, V., Sharma, N., Singh, B., and Mann, A. S. (2011). Scientific basis for the therapeutic use of Cymbopogon citratus, stapf (Lemon grass). Journal of Advanced Pharmaceutical Technology and Research, 2(1): 3-8.

Sessou, P., Farougoul, S., Kaneho, S.et al.(2012). Bioefficacy of Cymbopogon citratus essential oil against foodborne pathogens in culture medium and in traditional cheese wagashi produced in Benin. International Research Journal of Microbiology, 3(12) : 406-415.

Tajidin, E.N., Ahmad, S.H., Rosenani, A.B., Azimah, H., and Munirah, M. (2012). Chemical composition and citral content in lemongrass (Cymbopogon citratus) essential oil at three maturity stages. Afr. J.Biotechnol, 11: 26852693.

Tatiana, F. B., and José, M. S. (2011). Lemongrass and citral effect on cytokines production by marine macrophages. Journal of Ethnopharmacology,137: 909- 913.

Yèhouenou, B., Ahoussi, E., Sessou, P., Toukourou, F., and Sohounhloué, D. (2012).Chemical composition and antimicrobial activities of essential oils (EO) extracted from leaves of Lippia rugosa A. Chev against foods pathogenic and adulterated microorganisms. Afr. J. Microbiol. Res. 6: 5496-5505.

Zapataa, N., and Smagghea,G.(2010). Repellency and toxicity of essential oils from the leaves and bark of Laurelia sempervirens and Drimys winteri against Tribolium castaneum. Industrial Crops and Products, 32 : 405-410. 